\title{
BABY BOOM DALAM PERSPEKTIF DEMOGRAFIS DAN SOSIOLOGIS
}

\author{
Meidawati Suswandari \\ Pendidikan Guru Sekolah Dasar-Universitas Veteran Bangun Nusantara, Sukoharjo \\ Email: moetis meida@yahoo.co.id \\ MS.Khabibur Rahman \\ Pendidikan Geografi-Universitas Veteran Bangun Nusantara, Sukoharjo \\ Email: khabib.ynwa@gmail.com
}

\begin{abstract}
Abstrak
Tujuan penelitian ini adalah untuk mendeskripsikan Baby Boom dalam perspektif Demografis dan Sosiologis. Metode yang digunakan dalam penelitian ini adalah studi pustaka. Teknik pengumpulan data dalam penelitian ini yaitu dikumpulkan dari berbagai informasi baik dari media cetak (buku), maupun dalam jejaring (online internet. Selain itu, data yang terkumpul tersebut kemudian dianalisis, dipilih, dipilah dan disusun ulang menjadi suatu sajian yang mampu memberikan gambaran memadai tentang Baby Boom dalam Perspektif Demografis dan Sosiologis. Hasil penelitian ini dapat disimpulkan bahwa Baby Boom yang merupakan terjadinya ledakan jumlah kelahiran pada masa pandemi COVID-19 ini dapat dikaji dalam dua ranah, yaitu Perspektif Demografis dan Perspektif Sosiologis. Perspektif Demogratis memberikan makna bahwa COVID-19 yang berdampak pada Baby Boom ini adalah dipicu oleh faktor geografis dan struktur kependudukan. Perspektif Sosiologis memberikan makna bahwa COVID-19 yang berdampak pada Baby Boom ini adalah intentitas pasangan suami istri lebih intens di rumah dan apabila program KB tidak dilaksanakan yang akan berdampak kehamilan tidak direncanakan.
\end{abstract}

Kata Kunci: Baby Boom, Demografis, Sosiologis, COVID-19

\section{Abstract}

The purpose of this study was to describe the baby boom in demographic and sociological perceptions. The method used in this research is literature study. The data technique in this study was collected from various information both from printed media (books), as well as in networks (online), the internet. In addition, the collected data is then analyzed, selected, sorted and rearranged into a presentation capable of providing an adequate picture of the Baby Boom in a Demographic and Sociological Perspective. The results of this study reveal that the Baby Boom, which is an explosion in the number of births during the COVID-19 pandemic, can be studied in two areas, namely Demographic Perspective and Sociological Perspective. The Demographic Perspective means that COVID-19 which has an impact on the Baby Boom is triggered by geographic factors and population structures. The sociological perspective means that COVID-19 which has an impact on the Baby Boom is the intention of a husband and wife to be more intense at home and the family planning program is not implemented which will result in an unplanned pregnancy.

Keywords: Baby Boom, Demographic, Sociological, COVID-19 


\section{Pendahuluan}

Kategorisasi wabah COVID-19 sebagai pandemi dinyatakan oleh Organisasi Kesehatan Dunia atau WHO. Menurut WHO, pandemi merupakan merebaknya suatu wabah penyakit berskala global, dimana wabah penyakit tersebut telah menginfeksi penduduk dari ratusan negara. Pandemi tentunya berbeda dari endemi dan epidemi. Endemi merupakan tersebarnya wabah penyakit yang menjangkit wilayah tertentu. Contoh dari epidemi adalah misalnya wabah Ebola. Menurut WHO, Ebola merupakan penyakit yang endemi di negara Republik Demokratik Kongo. Kemudian, epidemi merupakan tersebarnya suatu wabah penyakit yang menginfeksi banyak orang dalam jangka waktu yang pendek. Epidemi dapat menjadi cikal bakal terjadinya suatu pandemi. Sebelum dikategorikan sebagai pandemi, wabah COVID-19 dikategorikan sebagai epidemi, dimana terjadi infeksi dalam jumlah yang besar dan dalam jangka waktu yang pendek di Republik Rakyat Cina dan di beberapa negara di Asia dan Eropa, sampai pada akhirnya menjadi pandemi karena telah berskala global, dengan jumlah kasus saat ini mencapai 300.000 lebih kasus dan menyebabkan 13.000 lebih kematian (Stahl, 2020).

Sementara itu, kasus wabah COVID-19 di Indonesia dikutip dari https://fixmakassar.pikiran-rakyat.com per 2 November 2020, dalam kurun waktu 24 jam jumlah kasus positif konfirmasi Covid19 bertambah hingga 2.618 kasus. Sementara itu, untuk pasien sembuh yang sebelumnya dinyatakan positif Covid-

$\underline{19}$ bertambah sebanyak 3.624 orang. Sehingga total pasien sembuh hingga saat ini mencapai 345.566 orang Untuk pasien meninggal akibat Covid19 bertambah sebanyak 101 orang. Dengan demikian, total pasien meninggal hingga saat ini mencapai $\quad 14.044 \quad$ orang dengan tingkat kematian 52 per 1 juta penduduk.

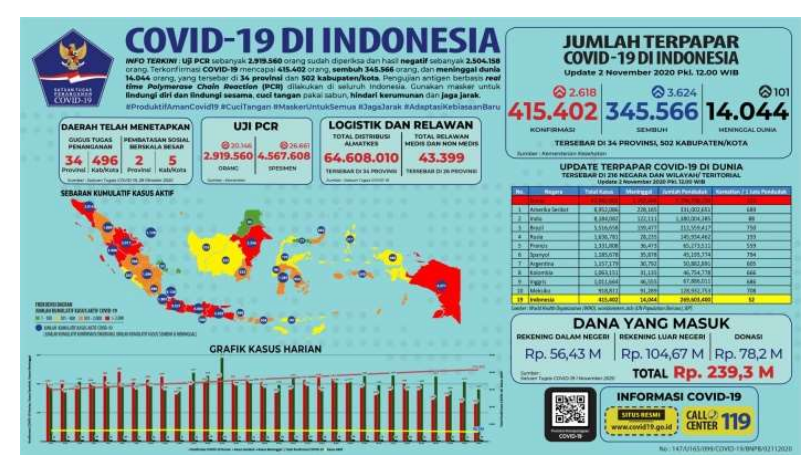

Gambar 1. Kasus COVID-19 di Indonesia per 2 November 2020 
Kebijakan khusus di Indonesia untuk memutus mata rantai COVID-19 terhitung mulai tanggal 29 Februari 2020. Langkah-langkah telah dilakukan oleh pemerintah untuk dapat menyelesaikan kasus luar biasa ini, salah satunya adalah dengan mensosialisasikan gerakan Social Distancing. Konsep ini menjelaskan bahwa untuk dapat mengurangi bahkan memutus mata rantai infeksi Covid-19 seseorang harus menjaga jarak aman dengan manusia lainnya minimal 2 meter, dan tidak melakukan kontak langsung dengan orang lain, menghindari pertemuan massal, rajin cuci tangan pada air mengalir, dan menggunakan masker (Buana, 2020).

Dampak lain pula dari COVID-19 menurut kementrian kesehatan (Kemenkes) PSBB membatasi seluruh kegiatan masyarakat, pembatasan dengan memberlakukan belajar dan bekerja didalam rumah, membatasi kegiatan keagamaan, pembatasan moda transportasi, pembatasan kegiatan ditempat umum dan meliburkan tempat kerja dan kegiatan lainnya khusus terkait aspek pertahanan keamanan (Nurwati, 2004; Putri, 2020).

Salah satu dampak di atas, seringkali menjadi dilematis bagi usia produktif. Karena terbatas akan aktifitas di luar rumah. Berdasarkan data pada tahun 2020 bahwa usia produktif adalah generasi millennial yaitu rentang usia 20 tahun hingga 40 tahun. Menurut data Badan Pusat Statistik (BPS), jumlah penduduk Indonesia usia 20 tahun hingga 40 tahun di tahun 2020 diduga berjumlah 83 juta jiwa atau $34 \%$ dari total penduduk Indonesia yang mencapai 271 juta jiwa (Hasanuddin, A \& Purwandi, 2020). Hal ini merujuk pula dari data tahun 2017, menurut CIA World Factbook tahun 2017, bahwa Indonesia merupakan negara dengan jumlah penduduk terbanyak urutan keempat di dunia, yaitu 260.580.739 jiwa atau 3,51 persen dari total penduduk dunia. Besarnya jumlah penduduk ini akan memengaruhi struktur umur penduduk, baik distribusi maupun komposisi penduduk. Dinamika struktur umur penduduk disebabkan oleh berlangsungnya proses demografi, meliputi fertilitas, mortalitas, dan migrasi penduduk yang saling berpengaruh satu sama lain (Andriani et al., 2018).

Apalagi pada masa pandemi COVID-19 ini, usia produktif dapat memunculkan baby boom. Baby boom adalah ledakan kelahiran bayi pada pasangan yang sudah menikah di atas 10 tahun, bukan pasangan baru. Karena, mereka tidak mengikuti program KB. 
Sehingga, kemungkinan besar mengharapkan anak ketiga dan kedua (republika.co.id).

Sementara itu, BKKBN mengajak membangun keluarga yang berkualitas dengan keluarga berketahanan di samping itu melalui program Keluarga Berencana (KB), setiap keluarga Indonesia diharapkan memiliki rata-rata 2 orang anak demi mewujudkan Penduduk Tumbuh Seimbang (PTS) pada tahun 2025, yang ditandai dengan Angka Fertilitas Total (TFR) sebesar 2,1. Dengan memiliki 2 anak dan jarak antar kelahiran minimal 3-5 tahun atau tidak ada dua balita dalam satu keluarga, maka orangtua memiliki kesempatan untuk memberikan asah, asih dan asuh secara penuh kepada anak (Lubis \& Mulianingsih, 2019).

\section{Adanya dampak COVID-19} tersebut munculah ketimpangan penduduk di Indonesia yang dalam hal ini dinamakan Baby Boom menjadikan kajian menarik untuk dibahas secara mendalam. Apalagi dengan kondisi masyarakat Indonesia yang multikultural dalam letak geografisnya maupun dari segi interaksi sosialnya. Oleh sebab itu, tujuan penelitian ini adalah untuk mendeskripsikan Baby Boom dalam perspektif Demografis dan Sosiologis.

\section{Metode}

Metode yang digunakan dalam penelitian ini adalah studi pustaka. Studi pustaka merupakan studi yang objek penelitiannya berupa karya-karya kepustakaan baik berupa jurnal ilmiah, buku, artikel dalam media massa, maupun data-data statistika. Literatur review ini digunakan untuk menggambarkan fenomena-fenomena yang ada, yang berlangsung pada saat ini atau saat yang lampau. Penelitian ini tidak mengadakan manipulasi atau pengubahan pada variable-variabel bebas, tetapi menggambarkan suatu kondisi apa adanya.

Teknik pengumpulan data dalam penelitian ini yaitu dikumpulkan dari berbagai informasi baik dari media cetak (buku), maupun dalam jejaring (online), internet. Selain itu, data yang terkumpul tersebut kemudian dianalisis, dipilih, dipilah dan disusun ulang menjadi suatu sajian yang mampu memberikan gambaran memadai tentang Baby Boom dalam Perspektif Demografis dan Sosiologis.

\section{Hasil dan Pembahasan}

Program KB terancam gagal
selama masa pandemi covid-19.
Kebijakan kerja dari rumah, belajar di
rumah, dan beribadah di rumah


menyebabkan terbatasnya akses masyarakat menuju fasilitas kesehatan. Keterbatasan akses ke fasilitas kesehatan berpotensi terhadap terjadinya kehamilan yang tidak diinginkan. Sejauh ini, terdapat penurunan jumlah pelayanan KB secara nasional dari masing-masing jenis alat obat kontrasepsi. Pasangan usia subur yang memerlukan kontrasepsi tidak bisa mengakses layanan kontrasepsi di fasilitas kesehatan atau mereka menunda kunjungan ke fasilitas kesehatan. Mereka khawatir tertular covid-19. Kekhawatiran yang lumrah sebagai manusia normal. Data yang disodorkan Kepala Badan Kependudukan dan Keluarga Berencana Nasional Hasto Wardoyo membuat mata terbelalak. Kata dia, rata-rata penggunaan alat kontrasepsi dari Februari hingga Maret secara nasional menurun sebanyak $40 \%$. Di daerah tertentu, seperti Banten dan Sulawesi Barat, angkanya mencapai $50 \%$. Karena itu, patut diantisipasi ledakan kelahiran anak. Bukan mustahil jumlah pertambahan penduduk sembilan bulan mendatang melebihi 4,5 juta jiwa. Laporan dari berbagai daerah membenarkan terjadinya peningkatan angka kehamilan. Di Kabupaten Nagekeo, Provinsi Nusa Tenggara Timur, selama masa pandemi covid-19 terdapat 1.946 kehamilan atau ada pertambahan 67 kehamilan dari tahun sebelumnya. Angka kehamilan di Sragen, Jawa Tengah, naik 10\%. (https://mediaindonesia.com).

Demikian pula, selama masa pandemik bahwa pasangan usia subur atau akseptor KB kemungkinan khawatir untuk datang ke fasilitas kesehatan, di lain pihak fasilitas kesehatan juga kekurangan Alat Pelindung Diri, sehingga timbul risiko putus-pakai pemakaian kontrasepsi yang akan berdampak kehamilan tidak direncanakan (https://fk.ugm.ac.id) . Hal ini juga dipertegas data dari Koran Media Indonesia, Senin 4 Mei 2020 bahwa ratarata penggunaan alat kontrasepsi dari Februari hingga Maret menurun $40 \%$. Terdapat penurunan peserta KB pada Maret 2020 apabila dibandingkan dengan Februari 2020 di seluruh Indonesia. Pemakaian IUD pada Februari 2020 sebanyak 36.155 , turun menjadi 23.383 , sedangkan implan dari 81.062 menjadi 51.536, suntik dari 524.989 menjadi 341.109 , pil 251.619 menjadi 146.767 , kondom dari 31.502 menjadi 19.583 , medis operasi pria (MOP) dari 2.283 menjadi 1.196, dan medis operasi wanita (MOW) dari 13.571 menjadi 8.093 (https://mediaindonesia.com).

Kewaspadaan adanya Baby Boom tersebut dapat kita kaji dalam dua perspektif yaitu Demografis dan 
Sosiologis.

\section{Baby Boom dalam Perspektif Demografis.}

PBB (1958) mendefinisikan bahwa demografi adalah studi ilmiah terhadap populasi manusia, terutama terhadap jumlah, struktur, dan perkembangannya. Masalah demografi lebih ditekankan pada perubahan dinamika kependudukan karena pengaruh perubahan fertilitas, mortalitas dan migrasi. Philip M.Hauser dan Dudley Duncan mendefinisikan bahwa demografi adalah ilmu yang mempelajari jumlah, persebaran, teritorial dan komposisi penduduk serta perubahanperubahannya dan sebab-sebab perubahan tersebut, yang biasanya timbul karena peristiwa kelahiran, kematian dan migrasi (gerak teritorial) dan mobilitas status.

Berkaitan dengan COVID-19 yang berdampak pada Baby Boom ini adalah dipicu oleh faktor geografis dan struktur kependudukan. Faktor geografis di Indonesia salah satunya adalah adanya kepadatan penduduk dibeberapa daerah khususnya kota-kota besar. Hal ini berkaitan erat menjadi salah satu faktor penyebab mengapa virus dapat menyebar lebih cepat. Menurut riset dari Katadata
Insight Center (KDC), terdapat beberapa faktor yang membuat daerah menjadi rentan terhadap penularan virus COVID19. Pertama terkait dengan karakteristik daerah yaitu kepadatan penduduk, kualitas udara, dan akses terhadap hunian layak. Kedua, terkait dengan kondisi kesehatan masyarakat yaitu jumlah perokok, jumlah lansia, dan jumlah kepemilikan jaminan kesehatan. Ketiga, terkait dengan risiko mobilitas penduduk (Marpaung, 2020; Mayasari \& Husin, 2014; Wulandari et al., 2020).

Dalam Studi Kependudukan, kependudukan sering disebut tenaga kerja atau manpower, dimana seluruh penduduk dianggap mempunyai potensi untuk bekerja secara produktif. Ketika PSBB berlaku banyak tenaga kerja di Indonesia terpaksa harus dirumahkan, karena mengingat penyebaran virus ini sangat cepat, dan seluruh perusahaan ikut merasakan dampaknya. Salah satu sektor yang luput dari analisis yakni bonus demografi Indonesia dimana bangsa Indonesia sedang menuju pada masa bonus demografi pada tahun 2028 (Nurwati, 2004).

Pembangunan kependudukan di Indonesia, jumlah remaja yang besar menjadi sangat potensial. Kedepannya, Indonesia mempunyai kesempatan untuk 
mendapatkan bonus demografi pada 1-3 dekade mendatang dimana remaja saat ini akan masuk pada usia produktif. Bonus demografi sendiri oleh beberapa peneliti diartikan sebagai keuntungan ekonomis yang disebabkan oleh menurunnya rasio ketergantungan sebagai hasil proses penurunan fertilitas jangka panjang (Adioetomo, SM, dkk, 2010). Di masa periode bonus demografi proporsi penduduk usia produktif di Indonesia diperkirakan mencapai $69 \%$ dari total penduduk, dimana rasio ketergantungan mencapai titik terendah. Artinya, pada periode tersebut jumlah angkatan kerja sangat besar sedangkan tanggungan beban kelompok tersebut terhadap kelompok usia anak dan lansia sangat rendah. Momentum ini harus dipersiapkan secara maksimal sehingga Indonesia bisa memanfaatkan peluang yang hanya terjadi sekali saja. Oleh karena itu perlu ada upaya yang kuat dari seluruh pihak terutama dalam meningkatkan kualitas Sumber Daya Manusia (SDM) sehingga Indonesia akan memiliki tenaga kerja yang berkompetensi dan memiliki daya saing tinggi (Suswandari, 2019). Bisa dibayangkan apabila remaja yang sekarang tidak dipersiapkan baik dari segi pendidikan dan keterampilannya maka dapat dipastikan kondisi Indonesia akan semakin terpuruk dalam kemiskinan karena generasi muda yang tidak produktif dan hanya menjadi beban Negara (Mayasari \& Husin, 2014; Radhitya et al., 2020; Yanti et al., 2020).

Generasi baby boom yang diiringi dengan penurunan kematian bayi makin lama akan menjadi dewasa dan mencapai usia kerja. Jumlah meningkat dengan pesat. Penurunan fertilitas yang kemudian mengikuti penurunan jumlah kematian bayi ini akan menyebabkan proporsi penduduk usia kerja semakin besar dibanding dengan proporsi penduduk muda. Apabila mereka ini terserap dalam pasar kerja dan mempunyai pekerjaan yang produktif, makan produksi per kapita akan meningkat. Penurunan fertilitas dan besarnya keluarga ideal akan memotivasi perempuan untuk masuk ke pasar kerja. Dengan masa melahirkan dan merawat anak menjadi lebih pendek, maka perempuan mempunyai waktu lebih banyak untuk melakukan hal-hal lain yang bukan melahirkan dan merawat anak. Perempuan yang masuk ke pasar kerja akan menyumbang pada peningkatan produksi per kapita (Mayasari \& Husin, 2014).

\section{Baby Boom dalam Perspektif Sosiologis}


Indonesia adalah negara yang mempunyai jumlah penduduk yang banyak. Jumlah penduduk Indonesia menempati urutan pertama negara di kawasan Asia Tenggara sedangkan menempati urutan ke-4 di dunia. Dengan jumlah $(215,27$ ju ta jiwa), Cina $(1,306$ milyar jiwa), India (1,068 milyar jiwa). Sebagai negara yang sedang berkembang Indonesia memiliki masalahmasalah kependudukan yang cukup serius dan harus segera diatasi agar tidak terjadi ledakan penduduk. Faktor-faktor penyebab terjadinya ledakan penduduk antara lain adalah : 1) jumlah penduduk yang besar; 2) pertumbuhan penduduk yang cepat; 3)penyebaran penduduk yang tidak merata; 4) banyaknya yang menikah di usia dini.; 5) program $\mathrm{kb}$ belum terlaksana dengan baik; 6) menurunnya angka kematian yang disebabkan oleh peningkatan perkembangan dalam bidang kesehatan atau medis; 7) banyak penduduk desa yang urbanisasi (Suartha, 2016).

Masalah ledakan pendudukan (baby boom) ini pada masa pandemi COVID -19 secara sosiologi dapat kita cermati bersama. Pendemi corona ini, anggaran negara banyak dipakai untuk kepentingan bangsa dan masyarakat Indonesia, sehingga bagi para pekerja honorer merasa resah dan takut di PHK karena tidak adanya anggaran. Dan sebagian bekerja dirumah namun tidak mendapatkan pendapatan apapun sehingga merasa resah akan keberlangsungan hidupnya pada masa pendemi ini (Nurwati, 2004).

Secara sosiologis kekhawatiran akan keberlangsungan hidup ini tidak terlepas dari sifat manusia sebagai makhluk sosial. Fenomena sosial yang terjadi dalam kehidupan manusia, merupakan suatu interaksi antara manusia dengan lingkungan alam. Bahkan hubungan antara manusia dengan sang penciptanya. Hal ini mengingat bahwa manusia merupakan sebagai makhluk sosial yang tidak bisa lepas dari antar keterkaitan manusia yang satu dengan satunya. Menurut Talcott Parsons, kehidupan sosial itu harus dipandang sebagai sebuah sistem sosial (Suswandari, 2017). la mengatakan bahwa dalam Narwoko dan Suyanto (2006: 125) sebuah sistem sosial dapat didefenisikan sebagai suatu pola interaksi sosial yang terjadi dari komponen sosial yang teratur dan melembaga. Salah satu karakteristik sistem sosial adalah merupakan kumpulan dari beberapa unsur atau komponen yang terdapat dalam masyarakat, dimana komponen- 
kompenen tersebut saling berhubungan dan saling tergantung satu sama lain. Kehidupan sosial sebagai suatu sistem sosial memerlukan terjadinya ketergantungan yang berimbas pada kestabilan sosial. Sistem yang timpang karena tidak adanya kesadaran bahwa mereka merupakan sebuah kesatuan, menjadikan sistem tersebut tidak teratur (Quraisy \& Tola, 2017).

Sistem yang tidak teratur dari kehidupan manusia khususnya dari dampak pandemi COVID-19 adalah apabila program KB tidak dilaksanakan maka akan terjadi hal-hal yang tidak diinginkan, seperti meningkatnya kemiskinan, kebodohan dan polarisasi sosial lainnya. Hal ini merupakan akibat laju pertumbuhan penduduk yang tidak seimbang dengan laju pertumbuhan ekonomi dan produksi sebagaimana teori Robert Malthus (1766-1834) tentang keseimbangan, yaitu keseimbangan antara deret ukur dengan deret hitung/fertility oy men-fertility of soil (Chuzaiman T. Yanggo dalam Halim, 2015).

Demikian pula, perspektif sosiologi dilihat dari fungsi keluarga yaitu sebagai reproduksi. Pada masa pandemi COVID19 ini, lebih banyak aktivitas tertuju di rumah. Tidak memungkiri bahwa intentitas pasangan suami istri lebih intens di rumah. Karena tiap anggota keluarga harus dapat mengekspresikan perasaan dan menyampaikan gagasan secara bebas dan nyaman. Suami dan istri harus dapat saling menerima, begitu pula orang tua ke anak dan sebaliknya. Kedekatan pun harus terbangun untuk membentuk keintiman yang akan menjadi kunci suksesnya komunikasi antarpersona di lingkungan keluarga. Keintiman di keluarga itu bukan sesuatu yang dapat diperoleh dengan mudah dan menunggu begitu saja. Itu adalah sesuatu yang harus diusahakan dan diciptakan dengan itikad dari masing-masing anggota keluarga.

Dilihat dari sisi keintiman dalam hubungan interpersonal, maka hubungan sosial yang terjalin harus memenuhi apa yang dinamakan need for intimacy. Batasan pengertian tentang intimacy, antara lain sebagai berikut. a) Intimacy melibatkan rasa saling memiliki (sense of belonging), yaitu kebutuhan untuk membuat hubungan kuat, stabil, dan dekat, b) Intimacy merupakan elemen emosional dalam suatu hubungan yang melibatkan pengungkapan diri (self disclosure), yang akan menghasilkan suatu keterikatan, kehangatan, dan kepercayaan, dan c) Intimacy adalah hubungan yang cukup kuat yang 
berlangsung dengan orang lain, yaitu ketika individu dapat saling berkorban untuk kesejahteraan satu sama lain tanpa harus kehilangan identitas masing-masing individu (Johnson dalam Permatasari et al., 2020).

\section{Simpulan}

Penelitian ini dapat disimpulkan bahwa Baby Boom yang merupakan terjadinya ledakan jumlah kelahiran pada masa pandemik COVID-19 ini dapat dikaji dalam dua ranah, yaitu Perspektif Demografis dan Perspektif Sosiologis. Perspektif Demografis memberikan makna bahwa COVID-19 yang berdampak pada Baby Boom ini adalah dipicu oleh faktor geografis dan struktur kependudukan. Faktor geografis dan struktur kependudukan di Indonesia karena kepadatan penduduk dibeberapa daerah khususnya kota-kota besar. Perspektif Sosiologis memberikan makna bahwa COVID-19 yang berdampak pada Baby Boom ini adalah intentitas pasangan suami istri lebih intens di rumah.

Karena tiap anggota keluarga harus dapat mengekspresikan perasaan dan menyampaikan gagasan secara bebas dan nyaman. Selain itu, apabila program KB tidak dilaksanakan dikarenakan pasangan usia subur atau akseptor KB kemungkinan khawatir untuk datang ke fasilitas kesehatan, di lain pihak fasilitas kesehatan juga kekurangan Alat Pelindung Diri, sehingga timbul risiko putus-pakai pemakaian kontrasepsi yang akan berdampak kehamilan tidak direncanakan

\section{Ucapan Terima Kasih}

Terima kasih kepada semua pihak yang telah mendukung penulisan artikel ini. Selanjutnya kami ucapkan terima kasih kepada redaksi Jurnal Dimensia yang telah menerbitkan tulisan ini.

\section{Daftar Pustaka}

Andriani, D. S., Pitoyo, A. J., \& Pangaribowo, E. H. (2018). Ketidaktercapaian Bonus Demografi: Pembelajaran dari Sumatera Barat. Populasi, 26(1), 1. https://doi.org/10.22146/jp.38685

Buana, D. R. (2020). Analisis Perilaku Masyarakat Indonesia dalam Menghadapi Pandemi Virus Corona (Covid-19) dan Kiat Menjaga Kesejahteraan Jiwa. SALAM: Jurnal Sosial Dan Budaya Syar-I, 7(3). https://doi.org/10.15408/sjsbs.v7i3.1 5082

Halim, F. (2015). Hukum dan Perubahan Sosial. Jurnal Al-Daullah, 4(1), 107115.

Hasanuddin, A \& Purwandi, L. (2020). Indonesia 2020: The Urban MiddleClass Millennials.

Lubis, B., \& Mulianingsih, S. (2019). Keterkaitan bonus demografi dengan teori generasi. Jurnal Registratie, 1(1), 21-36.

Marpaung, E. W. (2020). Pandemi COVID-19: Dampak Sosial-Ekonomi 
Tantangan , dan Potensi Solusi PANDEMI COVID-19. Jurnal UI, 1(1)(May), 1-15. https://doi.org/10.13140/RG.2.2.352 52.68483

Mayasari, S., \& Husin, A. (2014). Remaja Genre: Peluang Menuju Bonus Demografi. Demography Journal of Sriwijaya, 1(2), 4-8. https://www.neliti.com/publications/1 81646/remaja-genre-peluangmenuju-bonus-demografi

Nurwati, S. N. S. \& N. (2004). Dampak COVID-19 terhadap Tenaga Kerja di Indonesia. 03, 345-351.

Permatasari, A. N., Inten, D. N., Wiliani, W., \& Widiyanto, K. N. (2020). Keintiman Komunikasi Keluarga saat Social Distancing Pandemi Covid-19. Jurnal Obsesi: Jurnal Pendidikan Anak Usia Dini, 5(1), 346. https://doi.org/10.31004/obsesi.v5i1. 577

Putri, R. . (2020). Indonesia dalam Menghadapi Pandemi Covid-19. Jurnal IImiah Universitas Batanghari Jambi, 20(2), 705-709. https://doi.org/10.33087/jiubj.v20i2.1 010

Quraisy, H., \& Tola, S. F. (2017). Dinamika Sosial Kehidupan Pengusaha Warung Makan. Equilibrium: Jurnal Pendidikan, 3(2), 136-146.

https://doi.org/10.26618/equilibrium. v3i2.284

Radhitya, T. V., Nurwati, N., \& Irfan, M. (2020). Dampak Pandemi COVID-19 Terhadap Kekerasan dalam Rumah Tangga. Jurnal Kolaborasi Resolusi Konflik, 2(2), 111. https://doi.org/10.24198/jkrk.v2i2.29 119

Suartha, N. (2016). Faktor-Faktor Yang Mempengaruhi Tingginya Laju Pertumbuhan Dan Implementasi Kebijakan Penduduk Di Provinsi Bali.
Piramida, 12(1), 1-7.

Suswandari, M. (2017). Konstruksi Dialek Banyumasan Di Universitas Sebelas Maret. Edudikara: Jurnal Pendidikan dan Pembelajaran, 2(3), 257-267.

Suswandari, M. (2019). Cooperative Learning: Strategi Pengembangan Inovasi Pendidikan Di Indonesia. SCAFFOLDING: Jurnal Pendidikan Islam dan Multikulturalisme, 1(01), 16-24.

Wulandari, A., Rahman, F., Pujianti, N., Sari, A. R., Laily, N., Anggraini, L., Muddin, F. I., Ridwan, A. M., Anhar, V. Y., Azmiyannoor, M., \& Prasetio, D. B. (2020). Hubungan Karakteristik Individu dengan Pengetahuan tentang Pencegahan Coronavirus Disease 2019 pada Masyarakat di Kalimantan Selatan. Jurnal Kesehatan Masyarakat Indonesia, 15(1), 42. https://doi.org/10.26714/jkmi.15.1.20 20.42-46

Yanti, N. P. E. D., Nugraha, I. M. A. D. P., Wisnawa, G. A., Agustina, N. P. D., \& Diantari, N. P. A. (2020). Gambaran Pengetahuan Masyarakat tentang Covid-19 dan Perilaku Masyarakat di Masa Pandemi Covid-19. Jurnal Keperawatan Jiwa, Vol. 8 No.(3), 485-490.

Stahl, C. (2020, March 22). Live Blog / Coronavirus updates: Global cases top 300.000 , John Hopkins University reports. Retrieved from NBC News: https://www.nbcnews.com/health/he alth-news/live-blog/coronavirusupdates-over-80-million-americansundervirtual-lockdown-chinan1165876

https://fixmakassar.pikiranrakyat.com/nasional/pr57901482/update-covid-19-senin-2november-2020-tingkat-kematian-diindonesia-capai-52-per-1-juta- 
penduduk

https://mediaindonesia.com/editorials/det

ail_editorials/1999-waspadai-baby-

boom

https://mediaindonesia.com/politik-danhukum/309951/pandemi-covid-19bisa-picu-baby-boom).

BKKBN. 2017. Bonus Demografi. (Online). Tersedia di https://www.bkkbn.go.id/detailpost/b onus-demografi-meningkatkankualitas- penduduk-melalui-keluarga. https://republika.co.id/berita/nasional/umu $\mathrm{m} / 12 / 02 / 16 /$ lzh59m-baby-boombakal-terjadi-pada-2020. 